\title{
The checks and balances of party federalism: German federal government in a divided legislature
}

\author{
THOMAS BRÄUNINGER \& THOMAS KÖNIG \\ Mannheim Centre for European Social Research (MZES), University of Mannheim, \\ Mannheim, Germany
}

\begin{abstract}
In this study, we assess the potential for policy change of the German government of Helmut Kohl after unification combining party positions with formal bicameral settings in a spatial model of legislative action. We distinguish between two policy areas and two types of legislation, mandatory and non-mandatory legislation imposing either a symmetric or asymmetric power distribution between both German chambers. In order to identify German legislators' party positions in different policy areas, we use data from ECPR Party Manifesto research covering the period from German unification in 1990 to the end of the government of Helmut Kohl in 1998. We find that the federal government of Helmut Kohl had a policy leadership position until April 1991 with no procedural differences, but the gridlock danger for governmental proposals was higher on the societal than the economic dimension. Afterwards, the government's potential for policy change was considerably determined by the type of legislation, independently from the policy dimension. At the end of the Kohl era, the governmental policy leadership position was limited to policies that left even the opposition majority of German states better off. The procedural settings mattered greatly on the economic dimension, and the danger of gridlock on societal policy was smaller only for non-mandatory legislation.
\end{abstract}

\section{Does bicameralism matter for the German government's policy-making?}

Cross-national research concludes that the type of state organisation, whether federal or unitary, affects the success, speed and nature of governmental policy-making. Besides other institutional constraints or 'veto-points' (Immergut 1992: 8) such as election rules, presidentialism, central bank autonomy, constitutional courts, or referenda, the 'sovereignty' of the federal government and its incumbent parties is restricted by the type of legislature (Huber et al. 1993; Lijphart 1994). According to Katzenstein (1987), Germany must therefore be regarded as a semi-sovereign state. Its bicameral legislature binds governmental policy-making to the consent of a set of veto players (Tsebelis \& Money 1997). Even though the German federal government cannot initiate fast and radical policy change, German bicam- 
eral decision-making is considered to be slow but effective in the long run (Schmidt 1995: 17).

These findings on German bicameralism are presently debated in public policy analysis. Until German unification in 1990, decreasing foreign investment and increasing public debt indicated a need for policy change, but the government of Helmut Kohl was not in the position to reform obsolete frameworks for taxation, employment, education and health. According to Scharpf (1985: 335), there is a so-called federal 'joint decision trap' favouring political immobilism, because the state governments are unable to come to an agreement at the federal level. Lehmbruch (1976: 16) stresses two problems of German bicameralism when party majorities differ in both chambers, in the Bundestag and Bundesrat: first, the configuration of different party majorities may endanger the legitimacy of federal legislation, since the (informal) grand coalition necessary for policy change excludes party competition; second, the scope for political action is limited to the smallest common denominator, because any change in the status quo depends on the consent of both party camps.

The sceptical view of German bicameralism refers to two general conditions for German legislation not changed by unification: the formal provision that most German bills require the bicameral consent of the Bundestag and Bundesrat, and the divergence of legislators' policy positions on legislative proposals. On closer inspection, however, more than $40 \%$ of all proposals passed without bicameral consent and about $75 \%$ of the proposals of the Kohl government were adopted in spite of different party majorities. ${ }^{1}$ Both results generate the question whether previous approaches underestimated the functioning of German bicameralism, particulary the agenda-setting position of the federal government under different bicameral settings and the location of the status quo. While opposition parties recently supported governmental proposals on societal issues like immigration or organised criminality, the Kohl government was unable to pass tax reform. These events raise the question whether the governmental leadership position was also determined by policy domain-specific distances of bicameral party majorities.

In this paper, we focus on the policy domain-specific potential for policy change which enables German federal government to change the status quo under different bicameral settings. We assess its potential for policy change by the policy positions on economic and societal policy of all legislative actors in both chambers, the Bundestag and the Bundesrat. For the purpose of analysis, we measure and compare the modification of the governmental policy domain-specific leadership position on the win set of all procedural policy alternatives preferred by any Bundestag and/or Bundesrat majority against the status quo. Empirically, our analysis starts with Ger- 
man unification in 1990 and examines how the leadership position of the Kohl government changed in economic and societal policy until its end in October 1998. We hereby stress that policy outcomes result as intertwined consequences of legislators' behaviour and institutional constraints on that behaviour (Mueller 1997: 3f).

For our comparative study, we apply a spatial model of legislative action that predicts legislative outcomes on the basis of formal procedural settings, the agenda-setting proposal of the government, the location of legislators' policy positions and that of the legislative status quo (Krehbiel 1996; König \& Bräuninger 1997). To compare the governmental potential for policy change, we derive the spatial location of legislators' policy positions from their party programmes using data of the ECPR Party Manifesto Group, and we assume legislators to have complete and perfect information, i.e., all actors know the 'rules of the game', their own and other actors' policy positions and vice versa. Applying a spatial model of legislative action, we try to combine the topics of cross-national research and public policy analysis when linking the impact of incumbent and co-governing opposition parties' policy positions to constitutional inhibitors to the federal government's policy-making (Schmidt 1995: 16).

Our findings suggest that the leadership position of the Kohl government considerably decreased after German unification. Until April 1991, similar party majorities enabled the federal government to act extensively as the dominant agenda-setter. After April 1991, the Kohl government's potential for policy change was limited to the introduction of new policies that had to leave even the opposition majority of German states better off, in particular on the economic dimension. Moreover, when Bundestag and Bundesrat party majorities differed from January 1996 to October 1998, the governmental leadership position partly depended on the type of legislature, whether strongly or weakly bicameral. Our conclusion is that the German governmental potential for policy change is determined not only by the formal rules of bicameralism, but also by the policy domain-specific distribution of legislators' party-orientated policy positions.

The remainder of this paper is divided into three sections. In order to compare the effects of the two types of legislatures we first discuss the characteristics of German bicameralism. Second, we introduce our data on party policy positions. Next, we present our model of legislative action, which is finally applied to a comparative analysis of the federal government's potential for policy change in economic and societal affairs. 


\section{The history of German federalism between strong and weak bicameralism}

Bicameralism is a widespread feature of modern legislatures restricting legislative decision-making to two independent sets of legislative actors. While cross-national research considers bicameralism as merely one of many constitutional veto-points that all restrict policy change, social choice research stresses the advantages of bicameral legislatures. Compared to unicameral legislatures, bicameralism accordingly subjects any social choice to one more decision or approval. The merits of this additional provision are conceived as the potential to minimise external costs of decision-making when the representatives of the two chambers are elected from diversely arranged jurisdictions (Buchanan \& Tullock 1962: 232-5), to eliminate or reduce the likelihood of voting cycles (Hammond \& Miller 1987: 1156f; Brennan \& Hamlin 1992: 174) and to diminish the manipulative power of an agenda-setter (Levmore 1992: 149). According to Riker (1992: 168) bicameralism may also delay non-efficient agreements or even hinder majority decision-making when policies are uni-dimensional (Tsebelis 1995: 290).

Historically, bicameralism evolved from two major strands. When conflicting societal groups had to be effectively represented, two types of bicameral settings were established to guarantee the institutionalisation of the cleavage. The 'English type' originates from class-consciousness. Besides 'God-given' aristocrats, citizens claimed their representation due to their growing economic power. Later, the English type of bicameral representation was justified by the higher stability and efficiency stemming from upper house seniority (Loewenberg \& Patterson 1979: 120; Lane \& Ersson 1994: 247). The 'Federal type' emerged when nation-building required territorial integration of sovereign dynasties (Schüttemayer \& Sturm 1992: 520). Federal states are, therefore, often considered to employ bicameral legislatures in order to combine proportional representation with recognition of the constituent states (Roskin 1986: 9; Levmore 1992: 159).

Federalism and bicameralism correlate positively, but federalism is not the only reason for bicameralism. A number of unitary systems established upper chambers to increase the efficiency of decision-making by bringing in senatorial expertise rather than political conflicts (Campion 1953: 32). And although all federal states employ bicameral legislatures, the settings may be either strong or weak: strong bicameralism is defined as the incongruent composition of the chambers which have the same power in legislative decision-making. Conversely, if cameral representatives are congruently selected or bicameral power distribution is extremely asymmetrical, weak or insignificant bicameralism results, with one chamber having symbolic rather than real functions (Lijphart 1984: 99). 
The history of German bicameralism has witnessed both strong and weak forms of bicameral settings. At the beginning of the nineteenth century, confederations of dynasties - not of peoples - were constituted to overcome the territorial fragmentation of the First German Empire. The prime organ of the 1815 German Confederation was an assembly of state princes and governments with weighted votes when making decisions in limited confederation legislation (Laufer 1992: 26). It established a weak bicameral setting with prerogatives for the upper house. The draft constitution of the 1848 revolutionary National Assembly attempted to balance the two German hegemonies, Prussia and Austria, by strong bicameralism. The popularly elected lower house, the so-called Volkshaus, was to have been accompanied by an upper, so-called Staatenhaus whose members would have been delegates of both state governments and state legislatures. As it turned out, the revolution failed and with it the effort to install a territorially balanced German federation of the American type where decisions would have required the consent of both houses (Laufer 1992: 28f).

The subsequent North German Federation of 1867 provided for two chambers, the directly elected Reichstag and the Bundesrat whose members were representatives of the constituent state governments. Though the adoption of federal laws was formally dependent on the consent of both chambers, the Bundesrat was still the prime organ, with Prussia clearly dominating other constituent states. In this respect, the 1871 unification in the German Empire was not an end but a means for consolidating Prussian hegemony. The upper house, the Bundesrat, remained the dominant voting body in federal legislation and execution, while the freely elected Reichstag had no real power to challenge the Prussian-dominated federal government. The 1871 constitution already provided for two peculiarities of present German federalism: first, the upper house consisted of delegates from constituent states' governments, not of elected representatives of the people or state legislatures; second, functional federalism, i.e., though federal ministries dominated legislative agenda setting, the state governments implemented most federal legislation (Boldt 1991: 308). As a result, German bicameralism historically promoted co-operation rather than separation between the federal and state level.

After World War I and the November revolution of 1918, the defeat of both the German Emperor and the state princes offered the opportunity to change the distribution of power between the lower and upper houses. The principle of popular sovereignty was strengthened by empowering the directly elected Reichstag at the expense of the Reichsrat as the successor of the Bundesrat. In federal legislation, the Reichsrat was only conceded a suspensive veto. Moreover, the constitution of the Weimar Republic was more unitary than any similar document in German history. Most competencies were defined on 
concurring legislation, i.e., the federal government could choose whether to engage in legislation or not. Though the process of unitarisation was already enforced in the Weimar Republic - coming to a climax with the 1932 Prussian coup d'état of the Reich chancellor becoming the commissioner of Prussia - the Nazi regime put an end to the federal organisation of the state. It first forced German States into following (the party) line and then in 1934 abolished the Reichsrat altogether (Kilper \& Lhotta 1996: 50).

In 1949, in the aftermath of World War II, the Federal Republic of Germany represented a further attempt to organise the state along federal lines. It retained both traditional peculiarities of German federalism, co-operation between federal and state level, and state governmental delegation in the Bundesrat. Moreover, post-war German legislation became an exceptional federal phenomenon by providing for both types of bicameralism, i.e. either strong or weak bicameral settings. Besides constitutional amendments and revisions requiring two-thirds majorities in the Bundestag and Bundesrat, two legislative procedures apply for ordinary federal legislation: mandatory legislation is bound by the (majority) approval of both chambers, installing a strong version by requiring the consent of the Bundesrat, principally in cases that affect the interests and administration of the constituent states. In non-mandatory legislation the Bundestag has the final vote. Even though a majority decision of the Bundestag may be rejected by the Bundesrat with an absolute or two-thirds majority, this rejection can be overruled by the corresponding majority of the Bundestag. The right to overrule the Bundesrat accordingly establishes weak bicameralism and thus promotes a dominance of governmental majorities in the Bundestag.

Figures 1a and $1 \mathrm{~b}$ show the extensive form of German mandatory and non-mandatory legislative games. In both procedures we consider the federal government (FG) as the agenda-setter who decides whether to initiate policy change (proposal) or not (no proposal). After three readings, the Bundestag (BT) may either pass the governmental proposal by simple majority (approval), or undertake no action or disapprove the proposal respectively (no approval), both leading to the rejection of the proposal. If the Bundestag approves the governmental proposal by majority, it is then sent to the Bundesrat (BR) whose role varies according to the type of procedure. In the case of mandatory legislation, a strong bicameral provision requires a majority of state delegates' votes (consent); without the support of at least 35 of 69 Bundesrat votes the status quo prevails (no consent), meaning the rejection of the governmental proposal.

In the case of non-mandatory legislation, the Bundesrat may reject the government proposal with at least an absolute majority of the states' weighted votes (rejection); if not, the status quo is changed by the proposal (no re- 


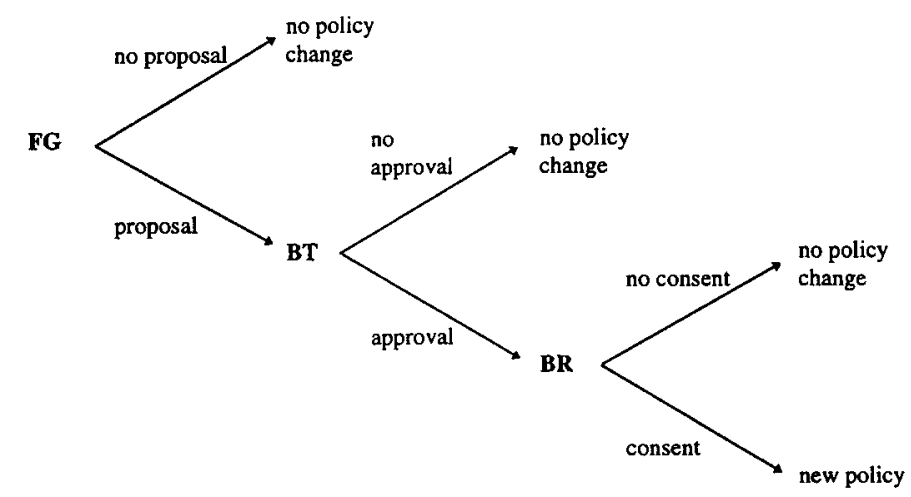

Figure 1a. Decision tree of German mandatory legislation (strong bicameral) on government bills. FG - Federal government; BT - Bundestag; BR - Bundesrat.

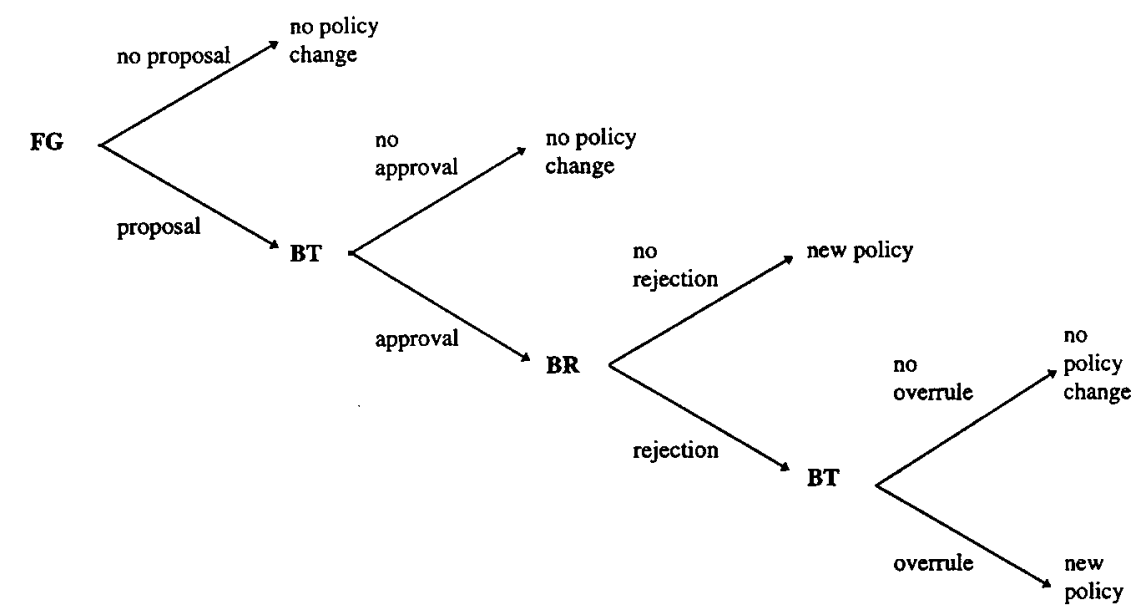

Figure 1 b. Decision tree of German non-mandatory legislation (weak bicameral) on government bills. FG - Federal government; BT - Bundestag; BR - Bundesrat.

jection). Due to the suspensive character of the Bundesrat rejection in the non-mandatory procedure, the Bundestag has the final decision whether either to overrule the rejection (overrule) or to refrain from doing so (no overrule). The governmental proposal is particularly endangered by a two-thirds rejection of the Bundesrat which has to be overruled by a corresponding Bundestag majority. Otherwise, non-mandatory legislation comes close to a unicameral parliamentary setting with the federal government and Bundestag majority in the Bundesrat acting in unison in federal legislation.

These differences raise the question of which procedure has to be applied for adopting governmental proposals. For their application, two aspects have to be mentioned. First, the constitution enumerates some legislative 
issues that allow for mandatory provisions, while the Constitutional Court decided that mandatory legislation has to be applied when a single issue of a proposal affects administrative responsibilities of state governments (Bryde 1989: 873). Second, mandatory legislation is not restricted to specific policy fields but applies whenever administrative responsibilities of state governments are affected. Not surprisingly, legislators often differ in their opinion concerning the type of legislation. Since 1949 about 5 to 10 percent of all proposals were subject to procedural debates, and since the mid-1970s about 5 percent of proposals became binding law in spite of a disagreement on procedural terms. ${ }^{2}$ Consequently, we assess strong and weak legislative channels in different policy domains.

The unambiguous application of both procedures requires a comparative view of bicameral settings, enabling us to study the impact of strong and weak bicameralism on governmental action in different policy domains. Moreover, our particular concern is with the effect of specific party majorities. When studying different situations of party majorities in the Bundestag and Bundesrat, we assess the policy domain-specific governmental leadership position with respect to both bicameral settings. We consider the question under what circumstances the federal government of Helmut Kohl was semi-sovereign, in the sense that the combination of the type of legislature with party majority configurations limited the governmental potential for policy change. In order to measure and compare the leadership position of the Kohl government, we draw our attention to legislators' policy positions under the period of study 1990-98.

\section{Policy positions of legislative actors}

The coverage of legislators' policy positions poses severe empirical problems for social choice analysis. When predicting legislative outcomes, we must collect actors' interests in specific policies in a way that describes the ex ante situation of decision-making (König 1997a: 130). Studying the impact of different procedural settings, varying party majorities and changing policy positions over time, we make simplifying assumptions about bicameral legislators' policy positions. We consider legislators' policy positions to indicate the actor-specific differences on a number of key dimensions that are representative for their positions on certain issues, and we estimate these positions empirically. Our comparative spatial analysis builds on three reference points located on rather different dimensions than issue-specific policy positions. It relates each legislator's policy position on the economic and societal dimensions with the agenda-setter's proposal and the location of the status quo. 
Table 1. Share of votes within the German Bundestag since unification

\begin{tabular}{|c|c|c|c|c|c|c|c|c|}
\hline Term & Time & $\mathrm{C}$ & $S$ & $\mathrm{~F}$ & G & $\mathrm{P}$ & Sum & $\begin{array}{l}\text { Federal } \\
\text { government } \\
\text { coalition }\end{array}$ \\
\hline 11 & $2.87-1.91$ & 223 & 186 & 46 & 42 & - & 497 & $\mathrm{C}-\mathrm{F}$ \\
\hline 12 & $1.91-10.94$ & 319 & 239 & 79 & 8 & 17 & 662 & $\mathrm{C}-\mathrm{F}$ \\
\hline 13 & $10.94-10.98$ & 294 & 252 & 47 & 49 & 30 & 672 & $\mathrm{C}-\mathrm{F}$ \\
\hline
\end{tabular}

For our analysis of the distances between the 672 representatives of the Bundestag, the 16 state and the Kohl governmental actors, we simplify the actor concept when conceiving of parties as the predominant source for legislative action. This is not an unreasonable assumption because parliamentary voting in the Bundestag has always been characterised by a high level of party discipline (Saalfeld 1995: 110; Beyme 1997: 271-91). Moreover, we use an average position for the location of the party policy position of governmental coalition partners. However, even though we disregard problems of intra-group preference aggregation among party representatives and coalition partners, we take account of the share of votes of each legislative actor (König \& Bräuninger 1996: 334). Table 1 shows the distribution of parliamentary groups' vote share in the Bundestag during the period under study. Since unification, the conservative-liberal government formed by the Christian Democrats (C) and the Free Democratic Party (F) was backed by the majority of Bundestag representatives, while the parliamentary opposition was made up of the Social Democrats (S), the Green Party $(G)$, and the Socialists (P).

In order to specify the reference points of our comparative analysis, we use data from a content analysis of party programmes conducted by the ECPR Manifesto Research Group (Budge, Robertson \& Hearl 1987; Laver \& Budge 1992; Klingemann, Hofferbert \& Budge 1994; Volkens 1997). Their main findings on the German party system suggest that the traditional 'left-right socio-economic' dimension is most important, but they also reveal the significance of other policy dimensions for German politics (Budge, Robertson \& Hearl 1987, chap. 18). For the late 1980s and early 1990s Volkens (1997) identifies different party distances on four major policy dimensions - the economic, the societal and the environmental dimensions, and the dimension of foreign and defence politics. The last dimension refers to the classic pro- 

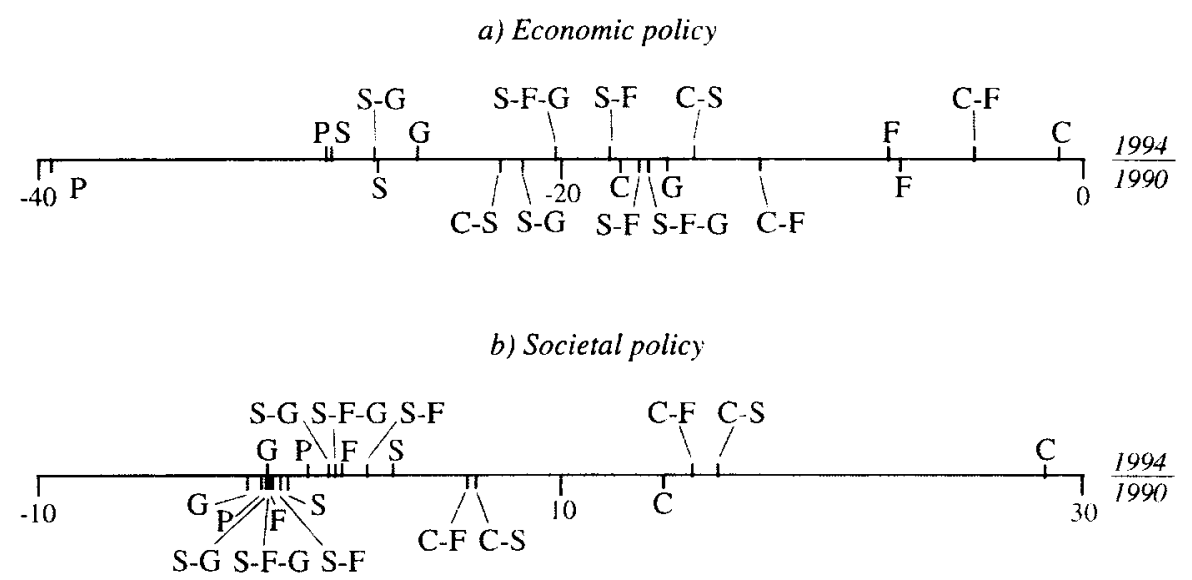

Figure 2. Parliamentary group and coalition cabinet policy positions in 1990 and 1994. Abbreviations: see Table 1.

tection function of political systems, whereas environmental conflicts might arise if the cleavage between materialists and post-materialists proves persistent. The first and second policy dimensions correspond to the key dimensions of the German party system, which have also been identified as the most important ones by mass survey data and expert judgements (Pappi 1973, 1984; Laver \& Schofield 1990; Laver \& Hunt 1992).

Referring to their findings, we compare the governmental potential for policy change on both key dimensions, on the economic and societal dimensions. For the period under study, Figures $2 \mathrm{a}$ and $2 \mathrm{~b}$ show the dimensionspecific distances of programmatic party and averaged coalition positions for the general elections of 1990 and $1994 .^{3}$ The lines represent the dimensions; below each line we show the results on programmatic party positions of 1990, above of 1994. Close to the lines we indicate the party positions, while the positions of coalition combinations are listed further from both lines.

- Policy positions on the economic dimension range from 'market regulation' on the left to 'free enterprise' on the right. According to Figure 2a, in 1990 the most state-centred policy position in economic affairs was held by the Party of Democratic Socialism (P), while the most conservative position on economic neo-liberalism was preferred by the Free Democratic Party (F). The centre ground was occupied by the Social Democratic Party (S) on the left and the Christian parties (C), closely followed by the Alliance '90/The Green Party (G), on the right. The economic dimension is largely characterised by distance changes in different directions. While the Christian parties took over the conservative position of their liberal coalition partner in 1994, the Greens moved 
more to the left when their Western part re-entered the Bundestag. In doing so, both parts basically returned to programmatic positions they held before German unification (Volkens 1997: 223).

- On the societal dimension the distance between Christian-conservative and all other parties is most striking (Figure $2 b$ ). The former puts much emphasis on 'law and order' and 'traditional morality' whereas all others are much more in favour of 'multiculturalism'. Compared to economic affairs, the Free Democratic Party (F) is even more 'liberal' than the Social Democrats (S), although the policy programmes of the nonChristian parties do not differ widely on societal issues. The ranking of parties has not changed from 1990 to 1994 on the societal dimension, but we observe a general conservative trend in party programmes on both dimensions.

For the purpose of analysis, we also use these data on party programmes to cover the policy positions of governmental actors, the federal government and the 16 state governments. Compared to the Bundestag, the 16 German states are represented by delegates of their governments with each delegation provided with three to six votes in the Bundesrat (Table 2). Since states have bloc votes requiring instruction by the state minister presidents, we can easily conceptualise the 16 delegations of the states as unitary actors. It is rather more difficult to determine governments' policy positions on the societal and economic dimensions, as the structure of state governments' positions is often considered to reflect the two-level nature of German federal legislation. In this context, Scharpf (1988: 239) developed his 'joint decision trap' approach, which is determined by the fact that federal decision making is dependent on the consent of the regional level, and state governments cooperate at the federal level under unanimity or quasi-unanimity (Scharpf 1994: 25). Under these conditions, federal decision making runs the risk of gridlock because federal actors are supposed to have distinct (federal) interests that differ from those of regional actors but are bound to the lower level's consent for decision-making.

According to the party-orientated approach, party politics dominates legislative decision-making in the Bundesrat, too. Federal and state governments are formed by parliamentary groups based on a common party system promoting policy positions to be structured along the party line. For this reason, Bundestag and Bundesrat are more likely to overcome the bicameral settings in the case of similar party majorities, while they are considered to be paralysed by immobility in the event of different party majorities, i.e., if a majority of states are governed by coalition partners belonging to the Bundestag opposition (Lehmbruch 1976: 156; Abromeit 1992: 142). The party-orientated approach classifies the decisive positions of Bundestag and 
Table 2. Share of votes within the German Bundesrat since unification

\begin{tabular}{|c|c|c|c|}
\hline \multirow[b]{2}{*}{ Since } & \multicolumn{3}{|c|}{ State governments grouped along party composition; votes } \\
\hline & $\begin{array}{l}\text { States of federal govern- } \\
\text { ment type }\end{array}$ & $\begin{array}{l}\text { States of federal opposi- } \\
\text { tion type }\end{array}$ & Mixed states \\
\hline $\begin{array}{l}11.90 \\
(68)\end{array}$ & $\begin{array}{l}\text { BA (C), BW (C), HE (C- } \\
\text { F), MW (C-F), RP (C-F), } \\
\text { SX (C), SN (C-F), TH (C- } \\
\text { F); } 35\end{array}$ & $\begin{array}{l}\text { BE (S-G), BM (S), LS (S- } \\
\text { G), NW (S), SA (S), SH } \\
\text { (S); } 26\end{array}$ & $\begin{array}{l}\text { BB (S-F-GÜ), HA (S-F); } \\
7\end{array}$ \\
\hline $\begin{array}{l}1.91 \\
(68)\end{array}$ & $\begin{array}{l}\text { BA (C), BW (C), HE (C- } \\
\text { F), MW (C-F), RP (C-F), } \\
\text { SX (C), SN (C-F), TH (C- } \\
\text { F); } 35\end{array}$ & $\begin{array}{l}\text { BM (S), LS (S-G), NW } \\
\text { (S), SA (S), SH (S); } 22\end{array}$ & $\begin{array}{l}\text { BE (C-S), BB (S-F-G), } \\
\text { HA (S-F); } 11\end{array}$ \\
\hline $\begin{array}{l}4.91 \\
(68)\end{array}$ & $\begin{array}{l}\text { BA (C), BW (C), MW (C- } \\
\text { F), RP (C-F), SX (C), SN } \\
\text { (C-F), TH (C-F); } 31\end{array}$ & $\begin{array}{l}\mathrm{BM}(\mathrm{S}), \mathrm{HE}(\mathrm{S}-\mathrm{G}), \mathrm{LS}(\mathrm{S}- \\
\mathrm{G}), \mathrm{NW}(\mathrm{S}), \mathrm{SA}(\mathrm{S}), \mathrm{SH} \\
(\mathrm{S}) ; 26\end{array}$ & $\begin{array}{l}\text { BE (C-S), BB (S-F-G), } \\
\text { HA (S-F); } 11\end{array}$ \\
\hline $\begin{array}{l}5.91 \\
(68)\end{array}$ & $\begin{array}{l}\text { BA (C), BW (C), MW (C- } \\
\text { F), SX (C), SN (C-F), TH } \\
\text { (C-F); } 27\end{array}$ & $\begin{array}{l}\text { BM (S), HE (S-G), LS (S- } \\
\text { G), NW (S), SA (S); SH } \\
\text { (S); } 26\end{array}$ & $\begin{array}{l}\text { BE (C-S), BB (S-F-G), } \\
\text { HA (S-F), RP (S-F); } 15\end{array}$ \\
\hline $\begin{array}{l}6.91 \\
(68)\end{array}$ & $\begin{array}{l}\text { BA (C), BW (C), MW (C- } \\
\text { F), SX (C), SN (C-F), TH } \\
(\mathrm{C}-\mathrm{F}) ; 27\end{array}$ & $\begin{array}{l}\text { BM (S), HA (S), HE (S- } \\
\text { G), LS (S-G), NW (S), SA } \\
\text { (S), SH (S); } 29\end{array}$ & $\begin{array}{l}\text { BE (C-S), BB (S-F-G), RP } \\
(\mathrm{S}-\mathrm{F}) ; 12\end{array}$ \\
\hline $\begin{array}{l}12.91 \\
(68)\end{array}$ & $\begin{array}{l}\text { BA (C), BW (C), MW (C- } \\
\text { F), SX (C), SN (C-F), TH } \\
\text { (C-F); } 27\end{array}$ & $\begin{array}{l}\text { HA (S), HE (S-G), LS (S- } \\
\text { G), NW (S), SA (S), SH } \\
\text { (S); } 26\end{array}$ & $\begin{array}{l}\text { BE }(\mathrm{C}-\mathrm{S}), \mathrm{BB}(\mathrm{S}-\mathrm{F}-\mathrm{G}), \\
\mathrm{BM}(\mathrm{S}-\mathrm{F}-\mathrm{G}), \mathrm{RP}(\mathrm{S}-\mathrm{F}) ; 15\end{array}$ \\
\hline $\begin{array}{l}5.92 \\
(68)\end{array}$ & $\begin{array}{l}\text { BA (C), MW (C-F), SX } \\
\text { (C), SN (C-F), TH (C-F); } \\
21\end{array}$ & $\begin{array}{l}\text { HA (S-STATT)*, HE (S- } \\
\text { G), LS (S-G), NW (S), SA } \\
\text { (S), SH (S); } 26\end{array}$ & $\begin{array}{l}\text { BE (C-S), BB (S-F-G), } \\
\text { BM (S-F-G), BW (C-S), } \\
\text { RP (S-F); } 21\end{array}$ \\
\hline $\begin{array}{l}7.94 \\
(68)\end{array}$ & $\begin{array}{l}\text { BA (C), MW (C-F), SX } \\
\text { (C), Th (C-F); } 17\end{array}$ & $\begin{array}{l}\text { HA (S-STATT), HE (S- } \\
\text { G), LS (S), NW (S), SA } \\
\text { (S), SN (S-G), SH (S); } 30\end{array}$ & $\begin{array}{l}\text { BE (C-S), BB (S-F-G), } \\
\text { BM (S-F-G), BW (C-S), } \\
\text { RP (S-F); } 21\end{array}$ \\
\hline $\begin{array}{l}9.94 \\
(68)\end{array}$ & $\begin{array}{l}\text { BA (C), MW (C-F), SX } \\
\text { (C), Th (C-F); } 17\end{array}$ & $\begin{array}{l}\text { BB (S), HA (S-STATT), } \\
\text { HE (S-G), LS (S), NW } \\
\text { (S), SA (S), SN (S-G), SH } \\
\text { (S); } 34\end{array}$ & $\begin{array}{l}\text { BE (C-S), BM (S-F-G), } \\
\text { BW (C-S), RP (S-F); } 17\end{array}$ \\
\hline $\begin{array}{l}10.94 \\
(68)\end{array}$ & $\mathrm{BA}(\mathrm{C}), \mathrm{SX}(\mathrm{C}) ; 10$ & $\begin{array}{l}\text { BB (S), HA (S-STATT), } \\
\text { HE (S-G), LS (S), NW } \\
\text { (S), SA (S), SN (S-G), SH } \\
(\mathrm{S}) ; 34\end{array}$ & $\begin{array}{l}\text { BE (C-S), BM (S-F-G), } \\
\text { BW (C-S), MW (C-S), RP } \\
\text { (S-F), TH (C-S); } 24\end{array}$ \\
\hline $\begin{array}{l}5.95 \\
(68)\end{array}$ & $\mathrm{BA}(\mathrm{C}), \mathrm{SX}(\mathrm{C}) ; 10$ & $\begin{array}{l}\text { BB (S), HA (S-STATT), } \\
\text { HE (S-G), LS (S); NW (S- } \\
\text { G), SA (S), SN (S-G), SH } \\
\text { (s); } 34\end{array}$ & $\begin{array}{l}\text { BE (C-S), BM (S-F-G), } \\
\text { BW (C-S), MW (C-S), RP } \\
\text { (S-F), TH (C-S); } 24\end{array}$ \\
\hline $\begin{array}{l}6.95 \\
(68)\end{array}$ & $\mathrm{BA}(\mathrm{C}), \mathrm{SX}(\mathrm{C}) ; 10$ & $\begin{array}{l}\text { BB (S), HA (S-STATT), } \\
\text { HE (S-G), LS (S), NW (S- } \\
\text { G), SA (S), SN (S-G), SH } \\
(\mathrm{S}) ; 34\end{array}$ & $\begin{array}{l}\text { BE (C-S), BM (S-C), BW } \\
\text { (C-S), MW (C-S), RP (S- } \\
\text { F), TH (C-S); } 24\end{array}$ \\
\hline $\begin{array}{l}1.96 \\
(69)\end{array}$ & $\mathrm{BA}(\mathrm{C}), \mathrm{SX}(\mathrm{C}) ; 10$ & $\begin{array}{l}\text { BB (S), HA (S-STATT), } \\
\text { HE (S-G)* LS (S), NW } \\
(\mathrm{S}-\mathrm{G}), \mathrm{SA}(\mathrm{S}), \mathrm{SN}(\mathrm{S}-\mathrm{G}), \\
\text { SH (S); } 35\end{array}$ & $\begin{array}{l}\text { BE (C-S), BM (S-C), BW } \\
\text { (C-S), MW (C-S), RP (S- } \\
\text { F), TH (C-S); } 24\end{array}$ \\
\hline
\end{tabular}


Table 1 (continued)

\begin{tabular}{|c|c|c|c|}
\hline \multirow[b]{2}{*}{ Since } & \multicolumn{3}{|c|}{ State governments grouped along party composition; votes } \\
\hline & $\begin{array}{l}\text { States of federal govern- } \\
\text { ment type }\end{array}$ & $\begin{array}{l}\text { States of federal opposi- } \\
\text { tion type }\end{array}$ & Mixed states \\
\hline $\begin{array}{l}4.96 \\
(69)\end{array}$ & $\begin{array}{l}\text { BA (C), BW (C-F), SX } \\
\text { (C); } 16\end{array}$ & $\begin{array}{l}\text { BB (S), HA (S-STATT), } \\
\text { HE (S-G), LS (S), NW (S- } \\
\text { G), SA (S), SN (S-G), SH } \\
\text { (S); } 35\end{array}$ & $\begin{array}{l}\text { BE (C-S), BM (S-C), MW } \\
\text { (C-S), RP (S-F), TH (C- } \\
\text { S); } 18\end{array}$ \\
\hline $\begin{array}{l}5.96 \\
(69)\end{array}$ & $\begin{array}{l}\text { BA (C), BW (C-F), SX } \\
\text { (C); } 16\end{array}$ & $\begin{array}{l}\text { BB (S), HA (S-STATT), } \\
\text { HE (S-G), LS (S), NW (S- } \\
\text { G), SA (S), SN (S-G), SH } \\
(\text { S-G); } 35\end{array}$ & $\begin{array}{l}\text { BE (C-S), BM (S-C), MW } \\
\text { (C-S), RP (S-F), TH (C- } \\
\text { S); } 18\end{array}$ \\
\hline $\begin{array}{l}11.97 \\
(69)\end{array}$ & $\begin{array}{l}\text { BA (C), BW (C-F), SX } \\
\text { (C); } 16\end{array}$ & $\begin{array}{l}\text { BB (S), HA (S), HE (S- } \\
\text { G), LS (S), NW (S-G), SA } \\
\text { (S), SN (S-G), SH (S-G); } \\
35\end{array}$ & $\begin{array}{l}\text { BE (C-S), BM (S-C), MW } \\
\text { (C-S), RP (S-F), Th (C-S); } \\
18\end{array}$ \\
\hline
\end{tabular}

* STATT - STATT Party Hamburg.

** Hesse 5 votes since 18/01/1996.

Source: Schindler (1994: 854), Esche and Hartmann (1990), Woyke (1994: 14), own compilation.

Abbreviations (Votes): BA - Bavaria (6), BB - Brandenburg (4), BE - Berlin (4), BM Bremen (3), BW - Baden-Württemberg (6), HA - Hamburg (3), HE - Hesse (4/5), LS - Lower Saxony (6), MW - Mecklenburg-West Pomerania (3), NW - North Rhine-Westphalia (6), RP Rhineland-Palatine (4), SA - Saarland (3), SH - Schleswig-Holstein (4), SN - Saxony-Anhalt (4), SX - Saxony (4), TH - Thuringia (4); see Table 1.

Bundesrat legislators, and different Bundestag and Bundesrat majorities increase the likelihood of bicameral gridlock (König 1997b: 153). However, even if we assume that Bundestag and Bundesrat policy positions are structured along their party lines, the high adoption rate of federal governmental proposals already indicates that different party majorities in both chambers do not necessarily lead to gridlock.

When classifying legislative actors according to their party orientation, another type of coalition cabinet emerges that belongs neither to the similar (and government supporting) nor to the different (and government opposing) party majorities category. Some state coalition governments of the Bundesrat consist of parties of both federal government majority and opposition minority parties. Since these 'mixed' states ${ }^{4}$ include both sides of the Bundestag, their coalition partners often agree to abstain from voting in the Bundesrat. Regarding both bicameral provisions, abstentions count against federal governmental proposals in mandatory legislation while they decrease the likelihood of a Bundesrat rejection in non-mandatory legislation. As mixedcabinet states often occupy an intermediate position in the Bundesrat, their votes are often decisive for the adoption of governmental proposals. For this 
reason, it is not surprising that the heads of state governments with mixed cabinets sometimes ignore their abstaining contract. In the history of the German Federal Republic, federal governments have only had the backing of similar party majorities in both chambers on one of three occasions. Most of the time, federal governments have been confronted by different or mixed party majorities. After unification, the Kohl government could expect party support in the Bundesrat until April 1991, but it had to deal with a majority of state governments whose coalition partners all belonged to the Bundestag opposition from January 1996 to its end in October 1988.

On closer inspection, even the extended party-orientated typology does not give a satisfactory account of the Bundesrat governmental policy positions, in particular when distinguishing between the economic and societal dimensions. To give a more realistic account, we try to differentiate between both dimensions by combining the party policy positions of coalition partners, whether single-party government or coalition cabinet (Figures 2a and 2b). Single-party state governments, like the Christian party government of Saxony or the Social Democratic party government of Lower Saxony are assumed to correspond to the programmatic positions of their parties. Using average positions we suppose the policy positions of coalition governments to be some sort of compromise between the party policy positions of their coalition partners. For example, we average the positions of the Christian and Liberal parties in order to locate the policy position of the Christian-Liberal federal government and of the state government of Baden-Württemberg.

The divide between states supporting or opposing the federal government in the Bundesrat becomes apparent on the economic and societal dimension: opposition state governments ruled by Social Democrats (S), coalitions of Social Democrats and Greens (S-G) or Social Democrat and Green coalitions supported by Socialists (S-G-P) preferred a more regulatory view of economic affairs and a more liberal view of societal policies than states belonging to the camp of the Kohl government. Due to the combination of party policy positions, mixed state governments indeed preferred policies between the policy positions of all other coalition parties. Under these assumptions, state governments ruled by Social Democrats had the most state-centred Bundesrat position on the economic dimension in 1990, followed by the Social Democratic/Green cabinets in 1994, whereas Social Democratic/Green coalition governments always had the most liberal position in the Bundesrat on the societal dimension.

In our view, our combination of party policy positions gives a rather accurate view of the distribution of legislators' policy positions on both dimensions We find economic policy positions to be distributed all over the policy space, while the societal policy positions of most legislative actors are 
located in the liberal sphere. When we conceive of the federal government as the dominant agenda-setter, we are able to ascertain the dimension-specific reference points of Christian-Liberal proposals and the decisive policy positions in the Bundestag and Bundesrat under both bicameral settings. From the governmental agenda setter's perspective, the median position is decisive in the Bundestag, while it is crucial to have the median position under mandatory and the one-third position under non-mandatory position in the Bundesrat. These dimension- and procedure-specific distances between the governmental agenda setter and the decisive Bundestag and Bundesrat legislators are major components of our spatial analysis, but the high adoption rate of governmental proposals suggests including another reference point in our spatial analysis, namely the location of the status quo.

Besides the agenda-setter and the decisive Bundestag and Bundesrat legislators, the location of the status quo has to be taken into account in order to reveal why German bicameralism promotes legislative gridlock on the economic dimension but even allows for constitutional changes in societal policy. To predict specific outcomes, spatial analysis relates each legislator's policy position to the location of the agenda-setter proposal and the status quo of the actual regulation. Compared to such predictive analyses, we consider all possible locations of the status quo in order to generalise our findings on all proposals that can be reduced to the economic and societal dimensions of German politics. We therefore apply comparative statics to all possible locations of the status quo.

\section{A spatial model of legislative action}

Our concern is the comparative analysis of the governmental potential for policy change in German economic and societal affairs. We analyse the policy leadership role of the federal government under weak and strong bicameral settings using a uni-dimensional spatial model of strategic voting with the federal government as the agenda-setter. The policy positions of all legislators are conceived of as their ideal points on each policy dimension, which is the policy that stands highest in their preference order. For any ideal point $x$ that is to the left of any $y$, we write $x<y$. Based on their ideal policies, legislators have Euclidean preferences, i.e., any distance from their ideal point leaves the actor worse off, irrespective of whether the policy is to the right or to the left (Ordeshook 1986: 25). For the sake of parsimony, we assume legislators to have similar distance functions. Actors with ideal points $x$ thus prefer a proposal $y$ to a proposal $z$ if and only if the distance from $x$ to $y$ is smaller than the distance from $x$ to $z(|x-y|<|x-z|)$. They are indifferent if and only if it is as far from $x$ to $y$ as it is to $z(|x-y|=|x-z|)$. Given these 
assumptions and that the federal government is the agenda-setter, legislators vote in favour of a governmental proposal $v$ if the proposal is closer to their ideal points $x$ than the status quo policy $s q(|x-v|<|x-s q|)$.

From the government's point of view, two aspects are important for its policy leadership role in bringing off policy change. First, the federal government must consider the location of decisive legislators' ideal points and the location of the status quo, as legislators will vote by comparing their distance to the new policy and to the status quo; the adoption of a governmental proposal accordingly requires a sufficient majority of legislators being closer to the proposal than to the status quo. Second, the federal government may focus on a few pivotal actors rather than all legislators when trying to provide the role of policy leadership. If government expects an arbitrary legislator to support its proposal shifting the status quo to the right, then it may assume all other legislators with ideal points to the arbitrary legislator's right are supporters of its proposal. In relation to the arbitrary legislator, their distance to the status quo increases when we consider the Euclidean preferences of all legislators. In this way, any approval depends on the decisive legislator(s) who make(s) the set of legislators to its right a majority.

Under German bicameral provisions, decisive legislators differ with respect to strong and weak bicameral settings. Using simple majority rule, legislators holding the median position $\left(m_{B T}, m_{B R}\right)$ in their chamber have the decisive vote that makes either the left or the right side a majority. Regarding a qualified two-thirds majority rule for Bundesrat rejection and Bundestag overrule in non-mandatory legislation, several decisive actors come into play. However, since the Kohl government held a conservative position on both policy dimensions with a right-wing supporting the Bundestag majority in the first stage, any Bundesrat rejection had to be supported by a majority of state governments on the left-hand side of the policy space in the second stage. Furthermore, the governmental party on the conservative right had to lead any Bundestag majority that afterwards rejected a suspensive veto of the Bundesrat. Therefore we must consider only the Bundesrat legislator as the decisive actor $\left(d_{B R}\right)$ who makes the left-wing of state delegates a twothirds majority in non-mandatory legislation, while we must take into account the parliamentary group in the Bundestag $\left(d_{B T}\right)$ that has the decisive vote in transforming the parties to its right into a two-thirds majority.

Table 3 lists median and two-thirds legislators and shows the orderings of decisive legislators' and the federal governments' ideal points $(g)$ on both policy dimensions for three periods of time: first, from unification to April 1991 when the Kohl government was backed by similar party majorities; second, from April 1991 to January 1996 with mixed majorities; and third, from January 1996 to the end of the Kohl era in October 1998 when dis- 
Table 2. Party affiliation of decisive actors in German mandatory and non-mandatory legislation in times of similar, mixed and different party majorities

\begin{tabular}{|c|c|c|c|c|c|}
\hline \multirow[b]{2}{*}{ Policy dimension } & \multicolumn{4}{|c|}{$\begin{array}{l}\text { Median }(m) \text { and two-thirds actors } \\
(d) \text { in the Bundestag }(B T) \text { and } \\
\text { Bundesrat }(B R)\end{array}$} & \multirow[b]{2}{*}{ Ordering of decisive actors } \\
\hline & $m_{B T}$ & $m_{B R}$ & $d_{B T}$ & $d_{B R}$ & \\
\hline \multicolumn{6}{|c|}{ Begin 12th term, 1.91-4.91 (Similar party majority) } \\
\hline Economic policy & $\mathrm{C}$ & $\mathrm{C}$ & $\mathrm{S}$ & S-F-G & $d_{B T}<m_{B T}=m_{B R}<d_{B R}=g$ \\
\hline Societal policy & $\mathrm{S}$ & $\mathrm{C}-\mathrm{F}$ & $\mathrm{S}$ & $\mathrm{C}-\mathrm{F}$ & $d_{B T}=m_{B T}<m_{B R}=d_{B R}=g$ \\
\hline \multicolumn{6}{|c|}{ Begin 13th term, 10.9-5.95 (Mixed party majorities) } \\
\hline Economic policy & $\mathrm{F}$ & S-F-G & $\mathrm{S}$ & $\mathrm{C}-\mathrm{S}$ & $d_{B T}<m_{B R}<d_{B R}<m_{B T}<G$ \\
\hline Societal policy & $\mathrm{S}$ & $\mathrm{S}$ & $\mathrm{S}$ & $\mathrm{C}-\mathrm{S}$ & $d_{B T}=m_{B T}=m_{B R}<g<d_{B R}$ \\
\hline \multicolumn{6}{|c|}{ End 13th term, 11.97-10.98 (Different party majorities) } \\
\hline Economic policy & $\mathrm{F}$ & S-G & $\mathrm{S}$ & $\mathrm{C}-\mathrm{S}$ & $d_{B T}<m_{B R}<d_{B R}<m_{B T}<g$ \\
\hline Societal policy & $\mathrm{S}$ & $\mathrm{S}$ & $\mathrm{S}$ & $\mathrm{C}-\mathrm{S}$ & $d_{B T}=m_{B T}=m_{B R}<g<d_{B R}$ \\
\hline
\end{tabular}

Abbreviations: See Table 1.

similar party majorities governed bicameral legislation. Considering the shift in the programmatic party policy positions over time, we use the 1990 data for the first period and the 1994 data for the second and third periods of our comparative study.

During the first period lasting from German unification to April 1991, the end of the Christian-Liberal state government in Hesse, the Kohl government was backed by similar party majorities in both chambers resulting in a strong emphasis of policy positions on the right-hand side of both policy dimensions. From January to April 1991, Christian parties (C) occupied the median position on both economic and societal dimensions not only in the Bundestag $\left(m_{R T}\right)$ but also in the Bundesrat $\left(m_{B R}\right)$ (Table 3). For most of the second period, state governments of the opposition and the mixed state category together held a majority in the Bundesrat. Right after the general election in October 1994 until June 1995, the Liberals (F) had the decisive median in the Bundestag and the S-F-G coalition cabinet of Bremen was the Bundesrat median in economic affairs while the Social Democrats (S) hold both decisive positions on the societal dimension.

Although these changes resulted from the loss of the Christian-Liberal majority in the Bundesrat, the 1994 right shift of the Christian parties (C) provided the Liberals (F) with the decisive median position on the economic dimension. As the parties' ranking on the two policy dimensions 
remained almost stable, all other modifications in decisive positions have been due to changing party majorities in the Bundesrat. Since 1994, the opposition Social Democrats (S) were also part of mixed cabinets that held the two-thirds position in the Bundesrat. These cabinets governed in Berlin, Baden-Württemberg, Mecklenburg-West Pomerania and Thuringia and decided on the suspensive character of a Bundesrat rejection $\left(d_{B R}\right)$.

In the Bundestag, Social Democrats always had the two-thirds vote $\left(d_{B T}\right)$ for suspending a Bundesrat majority rejection. Compared to the situation of similar party majorities, federal governments potential for policy change became therefore dependent on the voting behaviour of those mixed states. if mixed states abstained from voting, the federal government was not provided with a Bundesrat majority in mandatory legislation but there was also no twothirds majority of opposition state governments to impede policy change in non-mandatory legislation. Finally, the period of dissimilar party majorities was characterised by coalition cabinets of Social Democrats and Greens (S$\mathrm{G})$. The Kohl government was faced with dissimilar majorities from January 1996 to its end in October 1998. During this period, Social Democrats and Greens controlled the decisive Bundesrat median on the economic dimension.

Having identified the requirements of both bicameral settings, the agendasetter's and the decisive legislators' policy positions in the Bundestag and Bundesrat, we are able to compare the Kohl government's potential for policy change in weak and strong bicameral legislation. In this regard, we also compare the impact of different state majorities on the governmental potential for policy change. Given that all legislators have perfect and complete information, we assume that the government will behave as a strategic agenda-setter: the government tries to impose its ideal point or to propose a compromise when there is a sufficient majority to pass its proposal, while it will refrain from legislative action when it prefers the status quo. In short, the agenda-setter proposes the majority policy that is closest to itself. Our spatial model of legislative action accordingly applies a subgame perfect equilibrium concept (for details, see Appendix).

\section{Legislative leadership, compromise or abandonment}

In order to compare the federal government's potential for policy change we apply the spatial model of legislative action for strong and weak bicameral settings as well as for different periods of time on both dimensions. Considering possible changes of party policy positions, the decisive legislators may change with respect to bicameral settings, party majorities and periods of time. These comparative statics analyses show that first, strong and weak bicameral provisions indeed affected the federal government's potential for 


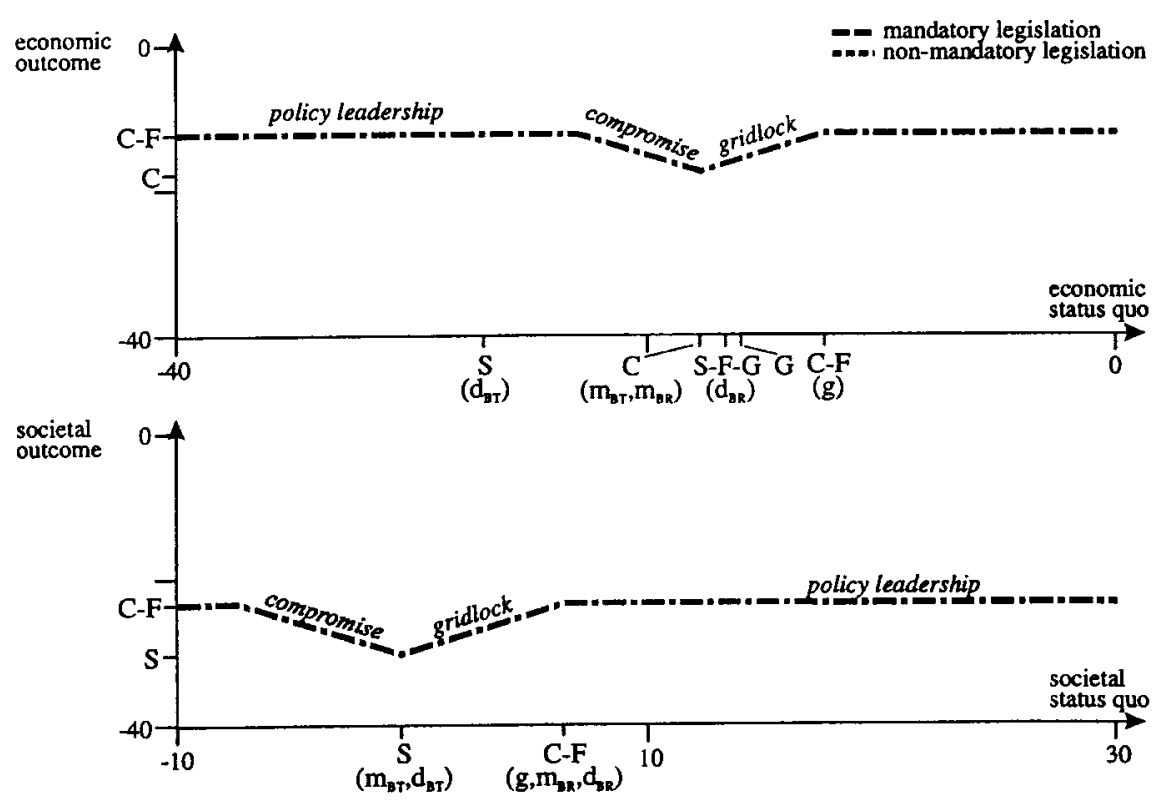

Figure 3. Federal government policy-making under similar party majority.

policy change, and second, German federal legislation was exposed to a high danger of gridlock as the party majorities changed from similar to mixed to dissimilar. However, these findings have to be qualified with respect to the different configurations in the Bundestag and Bundesrat. While the different bicameral settings had no impact on governmental potential for policy change when the federal government was backed by similar party majorities, legislative gridlock increased, particularly on economic issues, in times of mixed or different party majorities.

Figure 3 shows legislative outcomes on both dimensions in nonmandatory and mandatory legislation when similar party majorities in the Bundestag and Bundesrat facilitated governmental action. The vertical axis of these figures shows all legislative equilibria corresponding to any feasible status quo location along the horizontal axis. From the agenda-setter's point of view, we distinguish between three types of governmental choice:

- First, the federal government can act as a legislative leader and carry through its most preferred policy position. Such a convergence to the government's ideal point is due to the fact that the status quo is far enough from the decisive Bundestag and Bundesrat legislators' ideal points. Being the median in the Bundestag, the Christian parliamentary group (C) supported governmental proposals and, as the S-F-G cabinet of Brandenburg, the two-thirds actor in the Bundesrat, was even 
more market-liberal, both decisive legislators did not limit governmental action. This area is denoted by the horizontal line.

- Second, in a small area, the Kohl government refrained from acting as an agenda-setter and gridlock resulted irrespective of whether mandatory or non-mandatory legislation applied. This occurred when the status quo was located centrally between the federal government's and the Christian parliamentary group's ideal points because any governmental attempt to change the status quo to the right would have been disapproved of by the median in the Bundestag.

- Third, the federal government proposed a compromise when the status quo was left of but not too far from the Christian party's ideal policy. In this case the optimising federal agenda-setter adapted its preferred outcome in order to make the Bundestag's median actor at least indifferent. In societal politics, the Kohl government had to take into account the indifference of the Social Democrats as the median in the Bundestag. As both decisive positions in the Bundesrat are occupied by ChristianLiberal state governments, the Bundesrat hardly limited governmental action. The Bundestag's median and the federal government had similar distances on economic and societal matters. As a result, there was no difference in the gridlock and compromise intervals.

Finally, in the case of similar majorities of Christian Democrats and Liberals in both chambers, legislative outcomes under governmental agenda-setting differed with the location of the status quo but did not vary with respect to mandatory or non-mandatory legislation. Moreover, both procedural settings enabled collective governmental policy leadership of a rather majoritarian type with a high governmental potential for policy change. Considering governmental agenda-setting, federal government had a policy leadership role which was only bound by the centrally-located median voter in the Bundestag.

During the second period from April 1991 to January 1996, the Christianliberal federal government could not fall back on party support in both chambers but was instead confronted by a majority of opposing Social Democratic and mixed state governments. Figure 4 depicts legislative equilibria for the situation between October 1994 and June 1995. On the economic dimension, the delegates of the Bremen S-F-G state government were decisive for the consent of the Bundesrat while it was up to the C-S state governments to give the decisive vote for a two-thirds majority rejection in non-mandatory legislation. When compared to the configuration of similar party majorities, two key changes become apparent.

- First, gridlock became more likely and the federal government had to compromise more often on both dimensions. Two reasons have to be 


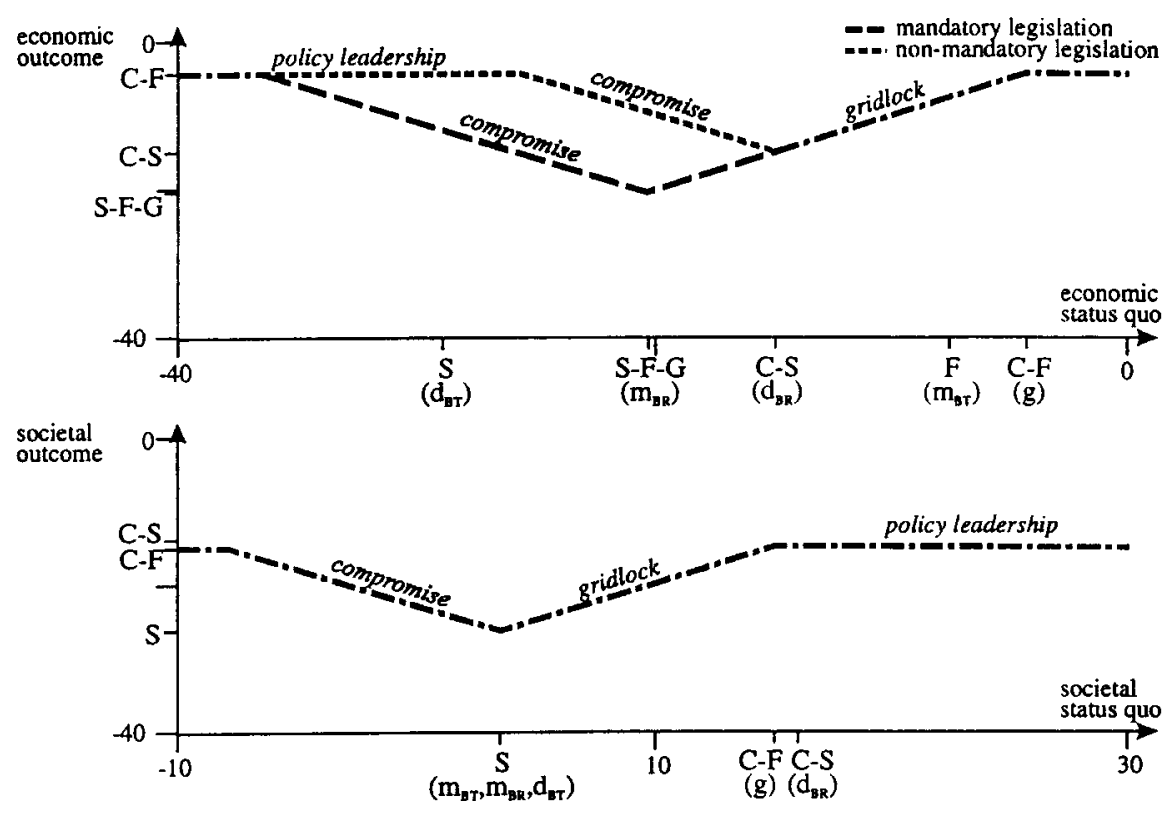

Figure 4. Federal government policy-making under mixed party majorities.

considered, namely the higher number of left-wing Bundesrat actors and, in addition, the Christian parties' shift to right and the Green party's shift to the left or economic matters which increased the distance between the decisive actors of bicameral legislation.

- Second, the procedural type of bicameralism made a difference for the governmental potential for economic policy change. In strong bicameral mandatory legislation, governmental policy change was not feasible with a status quo located between the federal and the S-F-G governments' ideal points. Within this interval the governmental agenda-setter and the Bundesrat median actor exclusively preferred policies either to the right or to the left.

Even though policy leadership became more difficult in weak bicameral nonmandatory legislation, the gridlock danger was high only for a status quo location ranging between the policy position of the Kohl government and the C-S cabinets. In societal policy, the federal government's potential for policy change also decreased due to changing Bundesrat majorities and party priorities. However, since the C-S state governments were even more conservative than the Kohl government, the two-thirds actors never came into play, and, as a result, there was no difference between strong and weak bicameral provisions on the societal dimension. 


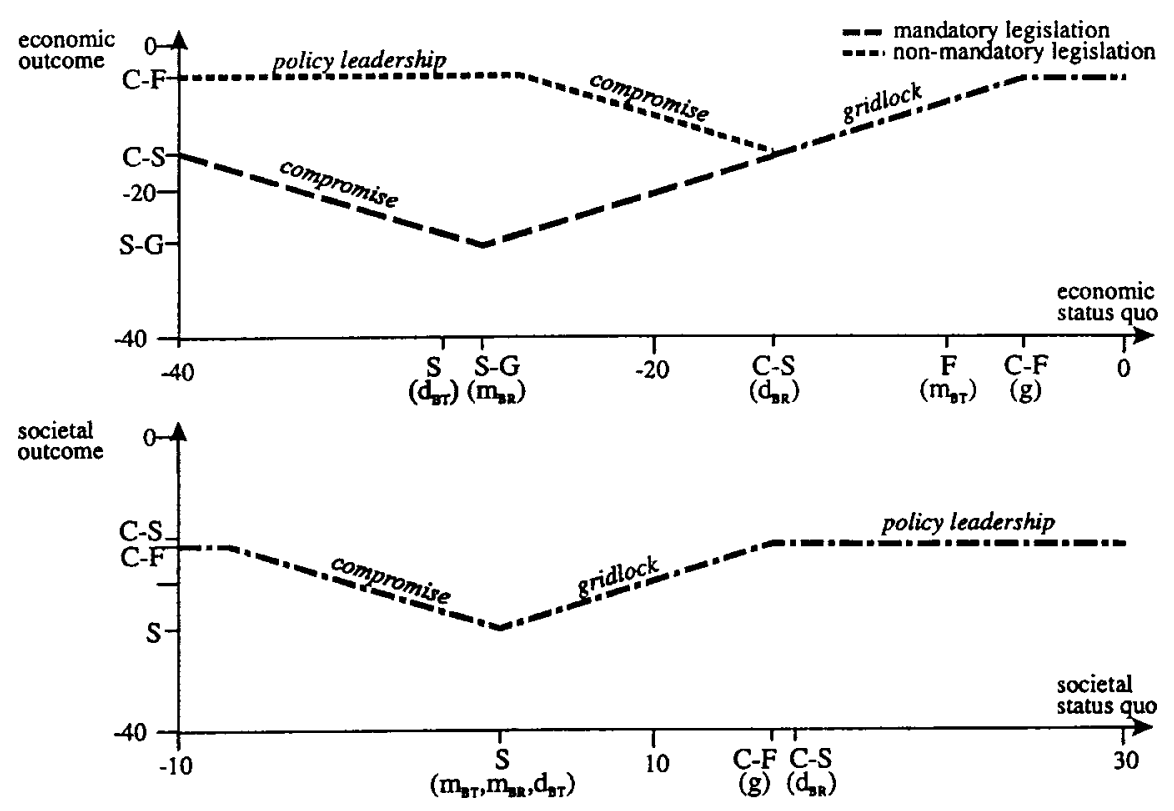

Figure 5. Federal government policy-making under different party majorities.

Finally, differences between both procedural settings became even more apparent during the last period of the Kohl government. Figure 5 shows the situation from November 1997 to the end of the 13th legislative term in October 1998. During this period, the S-G coalition cabinets of Hesse, North Rhine-Westphalia, Saxony-Anhalt and Schleswig-Holstein had the median position on the economic dimension and the Social Democratic governments on the societal dimensions implying the following consequences for the leadership position of the Kohl government:

- First, the left-wing Bundesrat median forced the governmental agendasetter to take their policy preferences into account when initiating mandatory legislation. Only when status quo points were located on the extreme poles of the party system could the federal government act as policy leader. For moderate status quo locations there was no governmental potential for policy change. Even if the status quo was marginally to the left of the S-G or Social Democratic cabinets' ideal points, the Kohl government could only compromise slight policy changes in mandatory legislation.

- Second, different party majorities did not expand the gridlock interval in non-mandatory economic legislation and on the societal dimension, since the C-S and Social Democratic state governments still had the two-thirds position of controlling a suspensive Bundesrat rejection on 
economic issues as well as the median position on governmental societal proposals.

Accordingly, the change from mixed to different party majorities did not affect societal policy which still had a lower gridlock danger than mandatory economic legislation. By contrast, we find procedural differences on the economic dimension. While the leadership position of the Kohl government was moderately limited in non-mandatory legislation, the transformation from similar to mixed to dissimilar party majorities significantly increased the danger of gridlock for mandatory economic proposals of the Kohl government.

\section{Conclusion}

In this paper we compared the German federal government's potential for policy change on different policy dimensions over time. We used a spatial model of legislative action to derive the government's leadership position by legislators' party preferences and formal bicameral settings. In order to assess empirically the governmental potential for policy change, we applied a policy dimension-specific concept of legislators' party policy positions. Moreover, we considered the governmental agenda-setting position and the decisiveness of bicameral legislators. We also took account of the effects of two different procedural settings, strong and weak bicameralism. Analysing legislative action in this way, we try to combine the topics of cross-national research and public policy analysis, and to clarify the relationship between institutional constraints, party majorities, the legislative status quo and the governmental potential for policy change on the main dimensions of the German party system.

Though considering modifications of party policy positions over time, we had to make simplifying assumptions about legislators' policy preferences. For the purpose of analysis, we disregarded the aggregation problem between party representatives and coalition partners when assuming programmatic party positions as ideal points of parliamentary groups and their average as ideal points of coalition governments. In particular for the agenda-setting federal government, one may suspect a closer governmental orientation to the median than to the positions of the coalition partners (Laver \& Shepsle 1996). Concerning state governments, we supposed a common federal party system, but state governments are formed on parties competing for state elections. However, when state governments take into account the federal party system for their Bundesrat voting behaviour, a collection of data on regional party programmes would not necessarily improve our bicameral analysis. Finally, when applying our spatial model of legislative action, we assumed actors 
to have complete and perfect information. As a consequence, we refrained from considering any kind of conciliation procedure. Relaxing some of these assumptions will certainly help to give a more realistic account of bicameral legislative action.

Under these assumptions, we find that first, the Kohl government's potential for legislative action considerably decreased after German unification. At the end of the Kohl era a 'semi-sovereign' government had little room to manoeuvre and was limited to new policies favourable even to states governed by the Bundestag opposition parties. Second, although the ordering of parliamentary groups as well as of state governments differed on the economic and societal policy dimensions, the federal government's potential for legislative action varies only moderately with the policy dimension. Third, federal government's potential for policy change partly depends on the type of legislation, i.e., strong or weak bicameral settings - but only in general and not always, nor under all circumstances. In the case of similar party majorities, the Kohl government could act extensively as the dominant agenda-setter under both bicameral settings. This was due to the fact that the procedural provision of a two-thirds rejection of the Bundesrat had no effect on the governmental leadership position because the Kohl government was only bound by the Christian parliamentary groups as the centrally located median voter in the Bundestag on economic and societal matters. This result may qualify general findings on German bicameralism claiming that procedural settings are always a powerful constraint impeding policy change.

\section{Acknowledgments}

For comments and suggestions, we are grateful to the participants of the workshop 'Does Federalism Matter?' at the European Consortium for Political Research Joint Sessions of Workshops, Warwick, March 23-28, 1998.

\section{Appendix}

Definition: A subgame perfect equilibrium (Selten 1965: 301-24; Ordeshook 1986: 137-42) in mandatory legislation is an equilibrium tuple $(v, b, z)$ with decision points of the federal government $(v)$, and the median actors in the Bundestag $(b)$ and Bundesrat (z); in non-mandatory legislation it is an equilibrium tuple $(v, b, e, u)$ with decision points of the federal government $(v)$, the median actor in the Bundesrat (e), and the median $(b)$ and the two-thirds actors $(u)$ in the Bundestag, if and only if: 
(i) Given a governmental proposal, the decision of each pivotal actor is the dominant strategy for the subgame.

(ii) The governmental proposal is the best alternative, i.e., federal government only initiates bills that, first, can be approved and second, there is no alternative bill that makes the government better off.

Proposition: Both mandatory and non-mandatory legislative games have a unique subgame perfect equilibrium $(v, b, z)$, or $(v, b, e, u)$. Let $m_{B T} \leqslant$ $m_{B R} \leqslant g$, unique equilibrium in mandatory legislation is given by:

$$
\begin{aligned}
& v= \begin{cases}g & \text { if } s q \leqslant 2 m_{B T}-g \text { or } g<s q \\
2 m_{B T}-s q & \text { if } 2 m_{B T}-g<s q<m_{B T} \\
\varnothing & \text { if } m_{B T} \leqslant s q \leqslant g\end{cases} \\
& b= \begin{cases}1 & \text { if }\left|v-m_{B T}\right| \leqslant\left|s q-m_{B T}\right| \\
0 & \text { if }\left|v-m_{B T}\right|>\left|s q-m_{B T}\right| \\
\varnothing & \text { if } v=\emptyset\end{cases} \\
& z= \begin{cases}1 & \text { if } b=1 \text { and }\left|v-m_{B R}\right| \leqslant\left|s q-m_{B R}\right| \\
0 & \text { if } b=1 \text { and }\left|v-m_{B R}\right|>\left|s q-m_{B R}\right| \\
\emptyset & \text { if } v=\emptyset \text { or } b=0\end{cases}
\end{aligned}
$$

where $\emptyset$ denotes the alternative of no action. If $m_{B R} \leqslant m_{B T} \leqslant g$ then interchanging $m_{B T}$ and $m_{B R}$ gives the equilibrium tuple. In non-mandatory legislation with $d_{B T} \leqslant m_{B T} \leqslant d_{B R} \leqslant g$ or $d_{B T} \leqslant m_{B T} \leqslant g \leqslant d_{B R}$ the unique equilibrium is given by:

$$
\begin{aligned}
& v= \begin{cases}g & \text { if } s q \leqslant 2 m_{B T}-g \text { or } g<s q \\
2 m_{B T}-s q & \text { if } 2 m_{B T}-g<s q<m_{B T} \\
\varnothing & \text { if } m_{B T} \leqslant s q \leqslant g\end{cases} \\
& b= \begin{cases}1 & \text { if }\left|v-m_{B T}\right| \leqslant\left|s q-m_{B T}\right| \\
0 & \text { if }\left|v-m_{B T}\right|>\left|s q-m_{B T}\right| \\
\varnothing & \text { if } v=\emptyset\end{cases} \\
& e= \begin{cases}1 & \text { if } b=1 \text { and }\left|v-d_{B R}\right|>\left|s q-d_{B R}\right| \\
0 & \text { if } b=1 \text { and }\left|v-d_{B R}\right| \leqslant\left|s q-d_{B R}\right| \\
\varnothing & \text { if } v=\emptyset \text { or } b=0\end{cases} \\
& u= \begin{cases}1 & \text { if } e=1 \text { and }\left|v-d_{B T}\right| \leqslant\left|s q-d_{B T}\right| \\
0 & \text { if } e=1 \text { and }\left|v-d_{B T}\right|>\left|s q-d_{B T}\right| \\
\varnothing & \text { if } v=\emptyset \text { or } b=0 \text { or } e=0\end{cases}
\end{aligned}
$$


Let $d_{B T} \leqslant d_{B R} \leqslant m_{B T} \leqslant g$ then:

$$
v= \begin{cases}g & \text { if } s q \leqslant 2 d_{B R}-g \text { or } g<s q \\ 2 d_{B R}-s q & \text { if } 2 d_{B R}-g<s q<d_{B R} \\ \emptyset & \text { if } d_{B R} \leqslant s q \leqslant g\end{cases}
$$

and $b, e$, and $u$ are given as above.

Proof: The proof is by backward induction (see Krehbiel 1996: König \& Bräuninger 1997: 627f).

\section{Notes}

1. Official database of the German Bundestag and Bundesrat (Stand der Gesetzgebung GESTA); own calculations.

2. GESTA; own calculations.

3. Estimation of party preferences is carried out in three steps (Laver \& Budge 1992; Klingemann, Hofferbert \& Budge 1994; Volkens 1997). First, for a set of 54 thematic categories, the relative emphasis a party programme devotes to each category is estimated as the proportion of all references to that category. In a second step, relative frequencies are summed up over those categories that are considered to belong to the same key dimension and to express either left- or right-wing references to the dimension in question. Finally, each party's position on a dimension is obtained as the net 'right minus left' difference of relative frequencies of references. As a result, scores can vary from -100 (most left) to +100 (most right).

4. Mixed states are also referred to as C-states (Schindler 1994: 852).

\section{References}

Abromeit, H. (1992). Der verkappte Einheitsstaat. Opladen: Leske + Budrich.

Beyme, K. von (1997). Der Gesetzgeber. Opladen: Westdeutscher Verlag.

Boldt, H. (1991). Der Föderalismus in den Reichsveifassungen von 1849 und 1871, in H. Wellenreuther \& C. Schnurmann (eds.), Die Amerikanische Verfassung und DeutschAmerikanisches Verfassungsdenken. Ein Rückblick über 200 Jahre (pp. 297-333). New York.

Brennan, G. \& Hamlin, A. (1992). Bicameralism and Majoritarian Equilibrium, Public Choice 74: $169-179$.

Bryde, B.-O. (1989). Stationen, Entscheidungen und Beteiligte im Gesetzgebungsverfahren, in H.-P. Schneider \& W. Zeh (eds.), Parlamentsrecht und Parlamentspraxis in der Bundesrepublik Deutschland. Berlin: de Gruyter.

Buchanan, J. M. \& Tullock, G. (1962). The calculus of consent: Logical foundations of constitutional democracy. Ann Arbor: University of of Michigan Press.

Budge, I. \& Keman, H. (1990). Parties and democracy. Coalition formation and government functioning in twenty states. Oxford: Oxford University Press.

Campion, Lord (1953). Second chambers in theory and practice, Parliamentary Affairs 7: $17-32$. 
Esche, F. \& Hartmann, J., eds. (1990). Handbuch der deutschen Bundesländer. Frankfurt a.M.: Campus.

Hammond, T. H. \& Miller, G. J. (1987). The core of the constitution, American Political Science Review 81: 1155-1174.

Huber, E., Ragin, C. \& Stephens, J. D. (1993). Social democracy, Christian democracy, constitutional structure, and the welfare state, American Journal of Sociology 99: 711-749.

Immergut, E. M. (1992). Health politics: Interests and institutions in Western Europe. Cambridge: Cambridge University Press.

Katzenstein, P. J. (1987). Policy and politics in West Germany: The growth of a semisovereign state. Philadelphia: Temple University Press.

Kilper, H. \& Lhotta, R. (1996). Föderalismus in der Bundesrepublik. Opladen: Leske + Budrich.

Klingemann, H.-D., Hofferbert, R. I. \& Budge, I. (1994). Parties, policies, democracy. Boulder, CO: Westview Press.

König, T. (1997a). Europa auf dem Weg zum Mehrheitssystem. Grunde und Konsequenzen nationaler und parlamentarischer integration. Opladen: Westdeutscher Verlag.

König, T. (1997b). Politikverflechtungsfalle oder Parteienblockade? Das Potential für politischen Wandel im deutschen Zweikammer-System, Staatswissenschaft und Staatspraxis 7: $135-159$.

König, T. \& Bräuninger, T. (1996). Power and political coordination in American and German multi-chamber legislation, Journal of Theoretical Politics 8: 331-360.

König, T. \& Bräuninger, T. (1997). Wie wichtig sind die Länder in der Einspruchs- und Zustimmungsgesetzgebung?, Zeitschrift für Parlamentsfragen 28: 605-628.

Krehbiel, K. (1996). Institutional and partisan sources of gridlock. A theory of divided and unified government, Journal of Theoretical Politics 8: 7-40.

Lane, J.-E. \& Ersson, S. O. (1994). Politics and Society in Western Europe, 3rd edn. London: Sage.

Laufer, H. (1992). Das föderative System der Bundesrepublik Deutschland. Bonn: Bundeszentrale für Politische Bildung.

Laver, M. \& Budge, I. (1992). Party policy and government coalitions. New York: St. Martin's Press.

Laver, M. \& Hunt, W. B. (1992). Policy and party competition. New York: Routledge.

Laver, M. \& Schofield, N. (1990). Multiparty government. The politics of coalition in Europe. Oxford: Oxford University Press.

Laver, M. \& Shepsle, K. A. (1996). Making and breaking governments. Cambridge: Cambridge University Press.

Lehmbruch, G. (1976). Parteienwettbewerb im Bundesstaat. Stuttgart: Kohlhammer.

Levmore, S. (1992). Bicameralism: When are two decisions better than one?, International Review of Law and Economics 12: 145-162.

Lijphart, A. (1984). Democracies. Patterns of majoritarian and consensus government in twenty-one countries. New Haven, CT: Yale University Press.

Lijphart, A. (1994). Democracies: Forms, performance, and constitutional engineering, European Journal of Political Research 25: 1-17.

Loewenberg, G. \& Patterson, S. C. (1979). Comparing legislatures. Lanham, MD: University of America Press.

Mueller, D. C. (1997). Public choice in perspective, in D. C. Mueller (ed.), Perspectives on public choice (pp. 1-17). Cambridge: Cambridge University Press.

Ordeshook, P. C. (1986). Game theory and political theory. Cambridge: Cambridge University Press. 
Pappi, F. U. (1973) Parteiensystem und Sozialstruktur in der Bundesrepublik, Politische Vierteljahresschrift 14: 191-213.

Pappi, F. U. (1984). The West German party system, West European Politics 7: 7-26.

Riker, W. H. (1992). The merits of bicameralism, International Review of Law and Economics 12: $166-168$.

Roskin, M. G. (1986). Countries and Concepts. Englewood Cliffs, NJ: Prentice Hall.

Saalfeld, T. (1995). Parteisoldaten und Rebellen. Fraktionen im Deutschen Bundestag 19491990. Opladen: Leske + Budrich.

Scharpf, F. W. (1985). Die Politikverflechtungs-Falle: Europäische Integration und deutscher Föderalismus im Vergleich, Politische Vierteljahresschrift 26: 323-356.

Scharpf, F. W. (1988). The joint decision trap: Lessons from German federalism and European integration, Public Administration 66: 239-278.

Scharpf, F. W. (1994). Optionen des Föderalismus in Deutschland. Frankfurt a.M.: Campus.

Schindler, P. (1994). Datenhandbuch zur Geschichte des Deutschen Bundestages. BadenBaden: Nomos.

Schmidt, M. G. (1995). The parties-do-matter hypothesis and the case of the Federal Republic of Germany, German Politics 4: 1-21.

Schüttemeyer, S. \& Sturm, R. (1992). Wozu Zweite Kammern? Zur Repräsentation und Funktionalität Zweiter Kammern in westlichen Demokratien, Zeitschrift für Parlamentsfragen 23: 517-536.

Selten, R. (1965). Spieltheoretische Behandlung des Oligopolmodells mit Nachfrageträgheit, Zeitschrift für die gesamte Staatswissenschaft 12: 301-324.

Tsebelis, G. (1995). Decision Making in Political Systems: Veto Players in Presidentialism, Parliamentarism, Multicameralism and Multipartyism, British Journal of Political Science 25: 289-325.

Tsebelis, G. \& Money, J. (1997). Bicameralism. Cambridge: Cambridge University Press.

Volkens, A. (1996) Parteiprogramme und Polarisierung, in O. Niedermayer (ed.), Intermediäre Strukturen in Ostdeutschland. Opladen: Leske + Budrich.

Woyke, W. (1994). Stichwort: Wahlen. Bonn: Bundeszentrale für politische Bildung.

Address for correspondence: Thomas Bräuninger, Mannheim Centre for European Social Research (MZES), Universität Mannheim, L7, 1, D-68131 Mannheim, Germany

Phone: +49621 2921701; Fax: +49621 2921784;

E-mail: thomas.braeuninger@mzes.uni-mannheim.de 